\title{
Carcass traits of sheep fed banana pseudostem hay
}

\section{Características de carcaça de ovinos alimentados com feno de pseudocaule de bananeira}

\author{
José Assunção Silveira Junior ${ }^{*}$; Márcio dos Santos Pedreira ${ }^{2}$; \\ Christian Albert Carvalho da Cruz ${ }^{3}$; Cristiane Leal dos Santos-Cruz ${ }^{2}$; \\ Cláudio Eduardo Silva Freitas; ; Alana Alves de Oliveira ${ }^{5}$; Maxwelder Santos \\ Soares ${ }^{6}$; Henrique Almeida da Silva ${ }^{7}$
}

\begin{abstract}
The objective of this study was to evaluate carcass yield, measurements, cuts, and fat deposition of sheep fed banana pseudostem hay and Tifton 85 grass hay, with or without virginiamycin. Thirty-three uncastrated male Dorper $\times$ Santa Ines crossbred lambs at five months of age, with an average body weight of $25.00 \pm 1.95 \mathrm{~kg}$, were used in a feedlot experiment. The following four diets were evaluated: Tifton 85 grass hay plus concentrate with virginiamycin, banana pseudostem hay replacing $60 \%$ of Tifton 85 grass hay plus concentrate with virginiamycin, Tifton 85 grass hay plus concentrate without virginiamycin, and banana pseudostem hay replacing $60 \%$ of Tifton 85 grass hay plus concentrate without virginiamycin. The experiment was set in a completely randomized design, in a factorial scheme, using orthogonal contrasts. The diet replacing $60 \%$ Tifton 85 grass hay by banana pseudostem hay without virginiamycin had no effect on carcass traits. The combination of virginiamycin and Tifton 85 grass hay provided increases in warm carcass weight, warm carcass yield, spine, omental and mesenteric fat deposition, and, regardless of roughage, increases in the thoracic perimeter.
\end{abstract}

Key words: Adipose tissue. By-product. Carcass quality. Feedlot. Virginiamycin.

\section{Resumo}

O objetivo deste estudo foi avaliar o rendimento, as medidas, os cortes e a deposição de gordura em ovinos alimentados com feno de pseudocaule de bananeira e feno de capim-tifton 85, com ou sem virginiamicina. Trinta e dois cordeiros mestiços Dorper $\times$ Santa Ines, não castrados, aos cinco meses de idade, com peso corporal médio de $25,00 \pm 1,95 \mathrm{~kg}$ foram utilizados no experimento em regime

\footnotetext{
1 Discente, Curso de Doutorado do Programa de Pós-Graduação em Zootecnia, PPZ, Universidade Estadual do Sudoeste da Bahia, UESB, Campus Juvino Oliveira, Itapetinga, BA, Brasil; Prof., Instituto Federal de Educação, Ciência e Tecnologia Baiano, IF Baiano, Campus Guanambi, Guanambi, BA, Brasil. E-mail: assuncaosilveira@gmail.com

2 Prof., Universidade Estadual do Sudoeste da Bahia, UESB, Departamento de Tecnologia Rural e Animal, DTRA, Campus Juvino Oliveira, Itapetinga, BA, Brasil. E-mail: mspedreira@gmail.com

3 Prof., Instituto Federal de Educação, Ciência e Tecnologia Baiano, IF Baiano, Campus Itapetinga, Itapetinga, BA, Brasil. E-mail christian.albert@hotmail.com

4 Discente, Curso de Doutorado do Programa de Pós-Graduação em Zootecnia, PPZ, Universidade Estadual do Sudoeste da Bahia, UESB, Campus Juvino Oliveira, Itapetinga, BA, Brasil. E-mail: eduardo-freitasmoc@hotmail.com

5 Eng $^{\text {a Agra }}$, Autônoma, Caetité, BA, Brasil. E-mail: lanacte123@hotmail.com

6 Discente, Curso de Doutorado do Programa de Pós-Graduação em Zootecnia, Universidade Estadual Paulista Júlio de Mesquita Filho, UNESP, Jaboticabal, SP, Brasil. E-mail: maxwelder10@hotmail.com

7 Zootecnista, Autônomo, Itapetinga, BA, Brasil. E-mail: henrique_brejoes@hotmail.com

* Author for correspondence.
} 
de confinamento. Foram avaliadas quatro dietas: feno de capim-Tifton 85 mais concentrado com virginiamicina; feno de pseudocaule de bananeira substituindo em $60 \%$ o feno de capim Tifton 85 mais concentrado com virginiamicina; feno de capim Tifton 85 mais concentrado sem virginiamicina; e feno de pseudocaule de bananeira substituindo em $60 \%$ o feno de capim Tifton 85 mais concentrado sem virginiamicina, em delineamento inteiramente casualizado, em arranjo fatorial $2 \times 2$ em contraste ortogonal. A substituição de $60 \%$ do feno de capim Tifton 85 por feno de pseudocaule de bananeira sem virginiamicina na dieta de ovinos não altera suas características de carcaça. A virginiamicina associada ao feno de capim Tífton 85 proporcionou aumento do peso de carcaça quente e do rendimento de carcaça quente, aumento do espinhaço, aumento das deposições de gorduras omental e mesentérica e, independente dos volumosos, aumento do perímetro torácico.

Palavras-chave: Confinamento. Qualidade de carcaça. Subproduto. Tecido adiposo. Virginiamicina.

\section{Introduction}

Sheep farming is an activity of considerable importance for the Brazilian livestock sector, given its great potential to supply meat products to the domestic market. This activity has grown significantly in the country the last decade, with a flock of 18,410,000 animals recorded in 2015. The northeast region of the country alone accounts for $60.6 \%$ of this figure (IBGE, 2015b).

Feedlotting is a rearing method that enables animal sales for slaughter during the off-season. In addition, it allows animal breeders to adopt nutritional strategies that anticipate slaughter, keeping the quality of carcass in good conditions and greater weight gains (MACEDO et al., 1999, 2000).

The use of crop residues can bring benefits to ruminant feeding by increasing animal production efficiency. Thanks to its constant and large production, the residues of banana crops (Musa sp.), which consist mainly of pseudostems, have become an alternative in animal nutrition (MANICA, 1997; MOREIRA, 1999).

Brazil has 530,300 ha planted with banana trees, and the northeast region corresponds to $39.75 \%$ of this area (IBGE, 2015a). According to Moreira (1999), banana crops under conventional cultivation practices generate approximately 180 to $200 \mathrm{t} \mathrm{ha}^{-1}$ year $^{-1}$ of crop residue, representing about $28 \mathrm{t}$ of dry matter.

Feed additives in ruminant nutrition may improve animal weight gain as well as feed efficiency, as a result of changes in rumen fermentation. According to Rogers et al. (1995), the use of virginiamycin in feedlot cattle diets improves carcass conversion by $7.8 \%$, average daily gain by $11.1 \%$, and feed conversion by $9.4 \%$.

Studies on sheep carcasses are important since they allow comparisons among genetic types, breeds, weights, and feeding systems. Carcasses can be marketed as whole carcass or as cut-up carcass products, which adds value to this product. By the same token, to assess carcass overall quality, it is important to examine the quality of each constituent part thereof.

Given the above, the objective of this study was to evaluate performance traits, measurements, cuts, and fat deposition in carcasses of Dorper $\times$ Santa Ines crossbred sheep fed banana pseudostem hay with and without virginiamycin supplementation.

\section{Material and Methods}

The experiment was carried out in Itapetinga - BA, Brazil (15¹5'12.48' S latitude and 40¹5'19.78' W longitude), in June 2016. Research on animals was conducted according to the institutional committee on animal use (case no.116/2015).

Thirty-two uncastrated male Dorper $\times$ Santa Ines crossbred (undefined genetic composition) lambs from random crossings, at approximately five months of age and $25.00 \pm 1.95 \mathrm{~kg}$ average body weight, were used in the trial. The lambs were housed in individual pens $(1.2 \mathrm{~m} \times 1.0 \mathrm{~m})$ with slatted floors, equipped with water and feed troughs. 
In the pre-experimental period, the animals were respectively numbered with an ear tag and then treated against endo- and ectoparasites with administration of Monepantel at $0.1 \mathrm{~mL} \mathrm{~kg} \mathrm{~kg}^{-1}$ (Zolvix $^{\mathrm{R}}$, Elanco Animal Health, Division of Eli Lilly Australia Pty Ltd) and coccidiostat at $20 \mathrm{mg}$ $\mathrm{kg}^{-1}$ (Isocox ${ }^{\mathrm{R}}$, Ourofino Saúde Animal, SP, Brazil), and also against clostridiosis (Exell 10 ${ }^{\mathrm{R}}$, Venco Saúde Animal, PR, Brazil).

The experiment lasted 99 days. The first 15 days were used for animal adaptation to the facilities and experimental diets, with a concentrated feed introduced gradually. The remaining 84 days were divided into four phases of 21 days for data collection. The animals were weighed on the first day and on the last day of each data collection phase; both the first and last weighing events occurred after a 16-hour solid feed deprivation period.

The four tested diets were formulated (Tables 1 and 2) as follows: total mixed ration (Tifton 85 grass hay and concentrate - TMR) with virginiamycin, banana pseudostem hay replacing $60 \%$ of TMR with virginiamycin addition, TMR without virginiamycin addition and banana pseudostem hay replacing $60 \%$ of TMR without virginiamycin addition. Lambs were randomly assigned to four treatments with eight replicates of one animal each.

Table 1. Chemical composition of Tifton 85 grass hay, banana pseudostem hay, virginiamycin concentrate, and concentrate without virginiamycin.

\begin{tabular}{lcccc}
\hline & \multicolumn{2}{c}{ Forage } & \multicolumn{2}{c}{ Concentrate } \\
\hline Characteristic & Tifton 85 Grass Hay & Banana Pseudostem Hay & With Virginiamycin & Without Virginiamycin \\
\hline DM & 83.9 & 80.5 & 89.3 & 88.5 \\
MM & 07.9 & 13.1 & 07.1 & 06.7 \\
CP & 20.1 & 03.8 & 21.1 & 21.0 \\
EE & 05.4 & 03.6 & 04.9 & 05.4 \\
NDF & 73.4 & 64.9 & 36.7 & 37.0 \\
NDFap & 60.3 & 58.2 & 29.6 & 30.2 \\
ADF & 48.5 & 42.1 & 22.7 & 22.8 \\
Lig & 14.5 & 07.5 & 01.6 & 01.8 \\
TCH & 66.4 & 79.5 & 67.0 & 67.9 \\
NFCap & 06.2 & 21.3 & 41.0 & 41.3 \\
TDN & 49.0 & 50.3 & 87.0 & 88.4 \\
iNDF & 16.8 & 21.4 & 07.7 & 05.3 \\
\hline
\end{tabular}

Note: dry matter (DM), mineral matter (MM), crude protein (CP), ether extract (EE), neutral detergent fiber (NDF), neutral detergent fiber corrected for ash and protein (NDFap), acid detergent fiber (ADF), lignin (Lig), total carbohydrates (TCH), nonfiber carbohydrates corrected for ash and protein (NFCap), total digestible nutrients (TDN), indigestible neutral detergent fiber (iNDF).

The product used as a source of virginiamycin was Eskalin ${ }^{\circledR}$, which has $98 \%$ calcium carbonate as its excipient and $2 \%$ virginiamycin. Dietary supply of virginiamycin was $17.4 \mathrm{mg} \mathrm{kg}^{-1}$ diet DM. The experimental diets were not isonitrogenous, being constituted with $40 \%$ roughage and $60 \%$ concentrate.

Before slaughter, deprived of solid feed for 16 $\mathrm{h}$, the following measurements were determined: perimeter of the rump, total leg length, thoracic perimeter, rump width and fasting body weight (OSÓRIO et al., 1998). 
The lambs were slaughtered after 84 experimental days. The slaughter procedures followed the Regulation for Industrial and Sanitary Inspection of Products of Animal Origin (RIISPOA, 1997). The animals were stunned by severing spinal cord in the atlantoccipital joint, using a pneumatic pistol, followed by bleeding through the jugular vein and carotid artery, the blood was collected and weighed, was followed by skinning and evisceration.

Table 2. Proportion and nutritional composition of the experimental diets based on dry matter.

\begin{tabular}{lcccc}
\hline Diet composition (\%) & TGHVM & BPHVM & TGH & BPH \\
\hline Tifton 85 grass hay & 40.00 & 16.00 & 40.00 & 16.00 \\
Banana pseudostem hay & 00.00 & 24.00 & 00.00 & 24.00 \\
Corn & 30.00 & 30.00 & 30.00 & 30.00 \\
Soybean meal & 03.00 & 03.00 & 03.00 & 03.00 \\
Soybean hulls & 18.00 & 18.00 & 18.00 & 18.00 \\
Wheat bran & 06.00 & 06.00 & 06.00 & 06.00 \\
Urea & 01.20 & 01.20 & 01.20 & 01.20 \\
Mineral Blend & 01.80 & 01.80 & 01.80 & 01.80 \\
\hline Total & 100.00 & 100.00 & 100.00 & 100.00 \\
\hline Experimental diet & & & & \\
Chemical composition (\%) & TGHVM & BPHVM & TGH & BPH \\
\hline DM & 87.13 & 86.33 & 86.65 & 85.86 \\
CP & 20.70 & 16.79 & 20.64 & 16.73 \\
EE & 05.10 & 04.67 & 05.40 & 04.97 \\
MM & 07.42 & 08.67 & 07.18 & 08.43 \\
TCH & 66.84 & 69.00 & 66.78 & 69.88 \\
NFCap & 27.08 & 30.70 & 27.26 & 30.88 \\
NDF & 51.38 & 49.34 & 51.56 & 49.52 \\
ADFap & 41.88 & 41.38 & 42.24 & 41.74 \\
ADF & 33.02 & 31.48 & 33.08 & 31.54 \\
Lig & 06.76 & 05.08 & 06.88 & 05.20 \\
iNDF & 11.34 & 12.44 & 09.90 & 11.00 \\
TDN & 71.80 & 72.11 & 72.64 & 72.95 \\
\hline
\end{tabular}

Note: dry matter (DM), crude protein (CP), ether extract (EE), mineral matter (MM), non-fiber carbohydrates corrected for ash and protein (NFCap), neutral detergent fiber (NDF), neutral detergent fiber corrected for ash and protein (NDFap), Acid detergent fiber (ADF), lignin (Lig), indigestible neutral detergent fiber (iNDF), total digestible nutrients (TDN). TGHVM - Tifton 85 grass hay highly concentrated with VM, BPHVM - banana pseudostem hay replacing $60 \%$ of the highly concentrated Tifton 85 grass hay with VM, TGH - Tifton 85 grass hay highly concentrated without VM, BPH - banana pseudostem hay replacing $60 \%$ of the highly concentrated Tifton 85 grass hay without VM.

Soon after slaughter, hot carcass weight was determined and used to estimate hot carcass yield. Afterward, the carcasses were taken to a cold room and chilled for $24 \mathrm{~h}$ at an average temperature of
$4{ }^{\circ} \mathrm{C}$, hung by the metatarsal joints on appropriate hooks, spaced about $17 \mathrm{~cm}$ apart. At the end of the period, cold carcass weight was determined, and cold carcass yield calculated. 
The carcass was weighed, measured internal carcass length and divided into the following anatomical cut-up parts: quarters, ribs, shoulder clods, neck, spine, perirenal fat, cavitary fat, omental fat, and mesenteric fat.

The left half-carcass was cross-sectioned between the $12^{\text {th }}$ and $13^{\text {th }}$ thoracic vertebra to expose the cross-section of the longissimus lumborum muscle. Still in the same muscle, the area corresponding to the cranial portion of loin was designed using a clear plastic film, thus establishing maximum width and depth for calculation of loin-eye area (LEA), as described by Cartaxo et al. (2011). For that purpose, the following formula was used: LEA $\left(\mathrm{cm}^{2}\right)=$ $(\mathrm{A} / 2 \times \mathrm{B} / 2) \pi$; wherein: $\mathrm{A}=$ width, and $\mathrm{B}=$ depth. Subcutaneous fat thickness was measured using a digital caliper at $11 \mathrm{~cm}$ from dorsolumbar line; this measure stands for the maximum fat thickness covering the $13^{\text {th }}$ rib surface (OSÓRIO et al., 1998).

The experiment was set up as completely randomized design arranged in a $2 \times 2$ factorial scheme, using orthogonal contrasts. The results were evaluated at 5\% significance level, using the GLM procedure of SAS (Statistical Analysis
System, version 9.1.), following the statistical model given below:

$$
\hat{\mathrm{Y}}_{i j k}=\mu+A_{i}+B_{j}+A B_{i j}+C_{k}+\varepsilon_{i j k},
$$

Wherein: $\hat{\mathrm{Y}}_{i j k}=$ observed measurement, $\mu=$ overall mean, $A_{i}=$ fixed effect of roughage, $B_{j}=$ fixed effect of virginiamycin, $A B_{i j}=$ effect of the interaction of factors, $C_{k}=$ random effect of lamb within treatment, and $\varepsilon_{i j k}=$ effect of the residual error.

\section{Results}

Dietary inclusion of banana pseudostem hay, with and without virginiamycin, had no effect on the slaughter weight, cold carcass weight, and cold carcass yield $(\mathrm{P}>0.05)$. On the other hand, hot carcass weight and hot carcass yield changed $(\mathrm{P}<0.05)$ with the inclusion of banana pseudostem hay plus virginiamycin, but showed lower values in comparison to the diet with Tifton 85 grass hay, as the sole source of roughage, plus virginiamycin. However, no change $(\mathrm{P}>0.05)$ was observed between both diets when none of them were supplemented with virginiamycin (Table 3).

Table 3. Carcass weight and yield of lambs receiving highly concentrated diets with Tifton 85 grass hay and banana pseudostem hay, with and without virginiamycin.

\begin{tabular}{|c|c|c|c|c|c|c|c|c|c|c|c|}
\hline \multirow{2}{*}{ Item } & \multicolumn{4}{|c|}{ Treatment } & \multirow{2}{*}{ Average } & \multirow{2}{*}{$\begin{array}{l}\text { CV } \\
(\%)\end{array}$} & \multicolumn{5}{|c|}{ Contrast ( $P^{*}$ value $)$} \\
\hline & TGHVM & BPHVM & $\mathrm{TGH}$ & $\mathrm{BPH}$ & & & 1 & 2 & 3 & 4 & 5 \\
\hline FBW (kg) & 45.32 & 44.54 & 43.77 & 42.65 & 44.07 & 8.6 & 0.207 & 0.424 & 0.316 & 0.688 & 0.551 \\
\hline HCW (kg) & 23.10 & 20.94 & 22.17 & 20.71 & 21.72 & 8.4 & 0.371 & 0.319 & 0.797 & 0.025 & 0.111 \\
\hline CCW (kg) & 21.88 & 20.51 & 21.26 & 19.94 & 20.90 & 8.8 & 0.369 & 0.511 & 0.537 & 0.149 & 0.154 \\
\hline $\mathrm{HCY}(\%)$ & 50.97 & 47.04 & 50.80 & 48.63 & 49.36 & 5.0 & 0.413 & 0.896 & 0.195 & 0.003 & 0.082 \\
\hline CCY $(\%)$ & 48.39 & 46.05 & 48.70 & 46.81 & 47.49 & 5.9 & 0.590 & 0.827 & 0.584 & 0.110 & 0.180 \\
\hline
\end{tabular}

Contrasts: 1- (TGHVM+ BPHVM) vs. (TGH + BPH), 2- TGHVM vs. TGH, 3- BPHVM vs. BPH, 4- TGHVM vs. BPHVM, 5- TGH vs. BPH. FBW - fasting body weight, HCW - hot carcass weight, CCW - cold carcass weight, HCY - hot carcass yield, CCY - cold carcass yield. TGHVM - Tifton 85 grass hay highly concentrated with VM, BPHVM - banana pseudostem hay replacing in $60 \%$ the highly concentrated Tifton 85 grass hay with VM, TGH - Tifton 85 grass hay highly concentrated without VM, BPH - banana pseudostem hay replacing $60 \%$ of the highly concentrated Tifton 85 grass hay without VM. *At a critical probability level of 0.05 . 
In terms of carcass measures, perimeter of the rump, total leg length, loin-eye area, rump width and internal carcass length, no significant changes $(\mathrm{P}>0.05)$. Thoracic perimeter measurements were higher $(\mathrm{P}<0.05)$ when virginiamycin was included, regardless of roughage type (Table 4 ).

The mean weights of quarters, ribs, shoulder clods, and neck showed no alteration ( $\mathrm{P}>0.05)$. Conversely, spine weights were lower in animals fed diet with banana pseudostem hay and virginiamycin
$(\mathrm{P}<0.05)$ than those of lambs fed a diet with Tifton grass hay and virginiamycin (Table 5).

The mean weights of mesenteric and omental fat depots were lower in carcasses of animals fed banana pseudostem hay with virginiamycin $(\mathrm{P}<0.05)$ if compared to those fed Tifton grass hay with virginiamycin. However, no weight changes were observed for the perirenal, cavity, and subcutaneous fats thickness $(\mathrm{P}>0.05)$ (Table 6).

Table 4. Carcass measurements of lambs receiving highly concentrated diets with Tifton 85 grass hay and banana pseudostem hay, with and without virginiamycin.

\begin{tabular}{|c|c|c|c|c|c|c|c|c|c|c|c|}
\hline \multirow{2}{*}{ Item } & \multicolumn{4}{|c|}{ Treatment } & \multirow{2}{*}{ Average } & \multirow{2}{*}{$\begin{array}{l}\text { CV } \\
(\%)\end{array}$} & \multicolumn{5}{|c|}{ Contrast (*P value) } \\
\hline & TGHVM & BPHVM & TGH & $\mathrm{BPH}$ & & & 1 & 2 & 3 & 4 & 5 \\
\hline $\mathrm{PR}(\mathrm{cm})$ & 67.12 & 66.19 & 65.00 & 63.50 & 65.45 & 14.1 & 0.461 & 0.649 & 0.554 & 0.841 & 0.741 \\
\hline TLL (cm) & 41.38 & 41.13 & 42.63 & 40.11 & 41.31 & 06.6 & 0.902 & 0.369 & 0.452 & 0.856 & 0.069 \\
\hline TP $(\mathrm{cm})$ & 76.81 & 76.58 & 75.12 & 74.06 & 75.64 & 03.7 & 0.042 & 0.243 & 0.078 & 0.868 & 0.444 \\
\hline $\operatorname{LEA}\left(\mathrm{cm}^{2}\right)$ & 19.13 & 18.76 & 17.19 & 16.82 & 17.98 & 19.6 & 0.126 & 0.281 & 0.267 & 0.839 & 0.833 \\
\hline $\mathrm{RW}(\mathrm{cm})$ & 22.94 & 22.25 & 22.25 & 21.34 & 22.19 & 08.0 & 0.221 & 0.445 & 0.327 & 0.445 & 0.327 \\
\hline $\operatorname{ICL}(\mathrm{cm})$ & 72.23 & 74.81 & 76.69 & 71.89 & 73.90 & 08.3 & 0.722 & 0.156 & 0.335 & 0.406 & 0.118 \\
\hline
\end{tabular}

Contrasts: 1- (TGHVM+ BPHVM) vs. (TGH + BPH), 2- TGHVM vs. TGH, 3- BPHVM vs. BPH, 4- TGHVM vs. BPHVM, 5TGH vs. BPH. RP - perimeter of the rump, TLL - total leg length, TP - thoracic perimeter, LEA - loin-eye area, RW - rump width, ICL - internal carcass length, BCI. TGHVM - Tifton 85 grass hay highly concentrated with VM, BPHVM - banana pseudostem hay replacing in $60 \%$ the highly concentrated Tifton 85 grass hay with VM, TGH - Tifton 85 grass hay highly concentrated without VM, BPH - banana pseudostem hay replacing $60 \%$ of the highly concentrated Tifton 85 grass hay without VM. *At a critical probability level of 0.05 .

Table 5. Ovine carcass cuttings receiving diets with Tífton grass hay and banana pseudostem hay highly concentrated with and without virginiamycin.

\begin{tabular}{|c|c|c|c|c|c|c|c|c|c|c|c|}
\hline \multirow{2}{*}{ Item } & \multicolumn{4}{|c|}{ Treatments } & \multirow{2}{*}{ Average } & \multirow{2}{*}{$\begin{array}{l}\text { CV } \\
(\%) \\
\end{array}$} & \multicolumn{5}{|c|}{ Contrasts $\left(P^{*}\right.$ value $)$} \\
\hline & TGHVM & BPHVM & TGH & BPH & & & 1 & 2 & 3 & 4 & 5 \\
\hline Quarter (kg) & 7.04 & 6.84 & 6.98 & 6.75 & 6.90 & 11.5 & 0.781 & 0.883 & 0.805 & 0.630 & 0.555 \\
\hline Rib (kg) & 5.17 & 4.68 & 5.04 & 4.75 & 4.91 & 13.4 & 0.886 & 0.696 & 0.851 & 0.147 & 0.373 \\
\hline Shoulder clod (kg) & 3.78 & 3.56 & 3.59 & 3.87 & 3.70 & 20.9 & 0.828 & 0.623 & 0.416 & 0.570 & 0.462 \\
\hline Neck (kg) & 1.30 & 1.31 & 1.31 & 1.18 & 1.28 & 18.2 & 0.473 & 0.932 & 0.267 & 0.966 & 0.249 \\
\hline Spine $(k g)$ & 3.94 & 3.29 & 3.60 & 3.31 & 3.53 & 11.1 & 0.247 & 0.098 & 0.947 & 0.003 & 0.137 \\
\hline
\end{tabular}

Contrasts: 1 - (TGHVM+ BPHVM) vs. (TGH + BPH), 2 - TGHVM vs. TGH, 3 - BPHVM vs. BPH, 4 - TGHVM vs. BPHVM, 5 TGH vs. BPH. TGHVM - Tifton 85 grass hay highly concentrated with VM, BPHVM - banana pseudostem hay replacing in $60 \%$ the highly concentrated Tifton 85 grass hay with VM, TGH - Tifton 85 grass hay highly concentrated without VM, BPH - banana pseudostem hay replacing $60 \%$ of the highly concentrated Tifton 85 grass hay without VM. *At a critical probability level of 0.05 . 
Table 6. Deposition of fat from sheep receiving diets with hay of Tifton 85 grass hay and of banana pseudostem hay highly concentrated with and without virginiamycin.

\begin{tabular}{|c|c|c|c|c|c|c|c|c|c|c|c|}
\hline \multirow{2}{*}{ Item } & \multicolumn{4}{|c|}{ Treatments } & \multirow{2}{*}{ Average } & \multirow{2}{*}{ CV $(\%)$} & \multicolumn{5}{|c|}{ Contrasts $\left(P^{*}\right.$ value $)$} \\
\hline & TGHVM & BPHVM & $\mathrm{TGH}$ & $\mathrm{BPH}$ & & & 1 & 2 & 3 & 4 & 5 \\
\hline $\mathrm{OF}(\mathrm{kg})$ & 1.40 & 1.00 & 1.27 & 0.97 & 1.16 & 26.3 & 0.472 & 0.407 & 0.859 & 0.015 & 0.054 \\
\hline MF (kg) & 0.66 & 0.34 & 0.59 & 0.45 & 0.51 & 44.2 & 0.746 & 0.582 & 0.306 & 0.008 & 0.205 \\
\hline SFT $(\mathrm{cm})$ & 0.21 & 0.24 & 0.31 & 0.26 & 0.25 & 83.6 & 0.465 & 0.375 & 0.893 & 0.749 & 0.651 \\
\hline $\mathrm{PF}(\mathrm{kg})$ & 0.61 & 1.00 & 0.70 & 0.50 & 0.70 & 47.2 & 0.845 & 0.557 & 0.745 & 0.557 & 0.132 \\
\hline $\mathrm{CF}(\mathrm{kg})$ & 0.14 & 0.11 & 0.10 & 0.13 & 0.12 & 43.7 & 0.663 & 0.138 & 0.356 & 0.163 & 0.309 \\
\hline
\end{tabular}

Contrasts: 1- (TGHVM+ BPHVM) vs. (TGH + BPH), 2- TGHVM vs. TGH, 3- BPHVM vs. BPH, 4- TGHVM vs. BPHVM, 5TGH vs. BPH. OF-omental fat, MF - mesenteric fat, SFT - subcutaneous fat thickness, PF - perirenal fat, CF - cavity fat. TGHVM - Tifton 85 grass hay highly concentrated with VM, BPHVM - banana pseudostem hay replacing in $60 \%$ the highly concentrated Tifton 85 grass hay with VM, TGH - Tifton 85 grass hay highly concentrated without VM, BPH - banana pseudostem hay replacing $60 \%$ of the highly concentrated Tifton 85 grass hay without VM. *At a critical probability level of 0.05 .

\section{Discussion}

Carcass traits revealed a discrete influence of treatments. Hot carcass weight and hot carcass yield were higher in the group of sheep receiving Tifton 85 grass hay with virginiamycin supply if compared with that fed banana pseudostem hay plus virginiamycin $(23.1 \mathrm{~kg}$ and $50.97 \%$ vs. 20.94 $\mathrm{kg}$ and $47.04 \%$, respectively).

In experiments with feedlot calves, no differences were found for hot carcass weight or hot carcass yield of animals supplemented with virginiamycin (MONTANO et al., 2015; LEMOS et al., 2016; NAVARRETE et al., 2017). In a trial with feedlot sheep receiving 60: 40 concentrate: roughage ratio diets, treatments using banana pseudostem hay as roughage provided better results compared to those with Cynodon sp. for fasting weight, hot carcass yield, and cold carcass weight, in addition to an equal performance for hot and cold carcass yields (CARMO et al., 2016). Yet, other authors found no differences for fasting weight, hot carcass weight, cold carcass weight, and carcass yield between sheep fed banana pseudostem and leaf hay and those fed Dichantium sp. hay (MARIE-MAGDELEINE et al., 2009).

Among the carcass measures (Table 4), only thoracic perimeter showed differences in the orthogonal contrast one, averaging 76.69 and $74.59 \mathrm{~cm}$ for diets with and without virginiamycin, respectively. The results obtained in the present study are similar to those reported for the loineye area in feedlot calves supplemented with virginiamycin (SALINAS-CHAVIRA et al., 2009, 2016; NAVARRETE et al., 2017). Carmo et al. (2016) observed no differences for thoracic perimeter, chest depth, rump width, internal carcass length, forelimb length, hindlimb length, subcutaneous fat thickness, or cooling loss rate in sheep receiving diets containing banana pseudostem hay and Cynodon sp. hay.

The results for subcutaneous fat thickness showed no differences in any of the contrasts used in this study. A minimum fat cover is desirable for meat preservation, as it reduces water loss and prevents shifts caused by cooling and freezing (Table 6).

The lack of statistical differences for loin-eye area reflected on carcasses showing a good degree of carcass finishing, averaging in $17.98 \mathrm{~cm}^{2}$ among all treatments (Table 4).

Changes in carcass cuts were only detected for spine, with means of 3,294 kg and $3,935 \mathrm{~kg}$ for animals fed diet with banana pseudostem hay and virginiamycin and, diet with Tifton grass 
hay and virginiamycin respectively (Table 5). As opposed to that, no differences were found for other cuts such as ribs, shoulder clods, and neck. Likewise, in a study with Holstein calves, the authors observed no differences among the group receiving virginiamycin, the control group, and the group receiving monensin for boneless cuts as a percentage of carcass weight (SALINASCHAVIRA et al., 2009, 2016). Also, in another study with feedlot sheep receiving Cynodon sp. hay or banana pseudostem hay as roughage sources, no changes were seen for carcass cuts such as the neck, shoulder clods, chest, and loin (CARMO et al., 2016).

Conversely, omental and mesenteric fat depositions showed differences (Table 6), with higher means for animals fed Tifton 85 grass hay with virginiamycin and for those receiving banana pseudostem hay plus virginiamycin. Nuñez et al. (2013) performed an experiment with feedlot Nellore calves and reported lower internal fat weights (perirenal, pericardial, and pelvic fats) and fat thickness for animals supplemented with virginiamycin plus salinomycin if compared to the group receiving only salinomycin. Meanwhile, the current study showed no significant differences in subcutaneous, perirenal, and cavity fats. In Holstein calves, no difference occurred for perirenal, pericardial, and pelvic fats as a percentage of carcass weight or subcutaneous fat thickness between the group receiving virginiamycin, the control group, and the group receiving monensin (SALINASCHAVIRA et al., 2009, 2016).

Navarrete et al. (2017) worked with Bos taurus taurus steers and found no difference between the group receiving virginiamycin and control group for subcutaneous, perirenal, pericardial, and pelvic fats. Our results corroborate those published by Carmo et al. (2016), who observed a similarity in subcutaneous fat thickness between feedlot sheep receiving Cynodon sp. hay and banana pseudostem hay, as roughage sources.
Some carcass traits of sheep fed Tifton 85 grass hay and virginiamycin had a better performance if compared to those of lambs receiving banana pseudostem hay plus virginiamycin (Tables 3, 5, and 6). This result can be attributed to improved use of crude protein (CP) in the rumen and small intestine promoted by virginiamycin supply, in a situation of greater CP uptake $(20.70 \%$ and $16.79 \%$, respectively) (Table 2). Another contributing factor was the amount of CP (20.1\%) in Tifton 85 grass hay (Table 1). In contrast five no difference was observed in itens evaluated (Tables 3, 4, and 5), comparing thes groups fed Tifton 85 grass hay and that fed banana pseudostem hay, both without virginiamycin addition, with 20.64 and $16.73 \%$ of CP, respectively) (Table 2).

Virginiamycin improves feed efficiency in the rumen and small intestine. In the rumen, it acts by reducing the population of Gram-positive proteolytic and amylolytic bacteria. As such, in a high-grain diet, it increases $\mathrm{pH}$, reduces ammoniacal nitrogen, and cause no changes in the population of fibrolytic bacteria (GUO et al., 2010). In feedlot Holstein calves, virginiamycin improved feed conversion (SALINAS-CHAVIRA et al., 2016) and increased the amount of dietary protein reaching the duodenum (MONTANO et al., 2015).

\section{Conclusions}

No changes in sheep carcass traits were observed by replacing $60 \%$ Tifton 85 grass hay in the diet with banana pseudostem hay, without virginiamycin supply.

\section{References}

CARMO, T. D.; FRANÇA, X. A. A.; GERASEEV, L. C.; VIEGAS, C. R.; COSTA NETO, P. P.; DUARTE, E. R.; BAHIENSE, R. N. Carcass characteristics and tissue composition of commercial cuts of lambs fed with banana crop residues. Semina: Ciencias Agrárias, Londrina, v. 37, n. 1, p. 393-404, 2016. DOI: 10.5433/1679-0359.2016v37n1p393 
CARTAXO, F. Q.; SOUSA, W. H.; COSTA, R. G.; COSTA, R. G.; CEZAR, M. F.; PEREIRA FILHO, J. M.; CUNHA, M. G. G. Características quantitativas da carcaça de cordeiros de diferentes genótipos submetidos a duas dietas. Revista Brasileira de Zootecnia, Viçosa, MG, v. 40, n. 10 , p. $2220-2227$, 2011. DOI: $10.1590 /$ S1516-35982011001000023.

GUO, T. J.; WANG, J. Q.; BU, D. P.; LIU, K. L.; WANG, J. P.; LI, D.; LUAN, S. Y.; HUO, X. K. Evaluation of the microbial population in ruminal fluid using real-time PCR in steers treated with virginiamycin. Czech Journal of Animal Science, Praga, v. 55, n. 7, p. 276-285, 2010. DOI: $10.17221 / 74 / 2009-C J A S$.

INSTITUTO BRASILEIRO DE GEOGRAFIA E ESTATÍSTICA - IBGE. Levantamento sistemático da produção agrícola. Rio de Janeiro. Centro de Documentação e Disseminação de Informações CDDI - Coordenação de Documentação e Biblioteca CDU, 2015a.

INSTITUTO BRASILEIRO DE GEOGRAFIA E ESTATÍSTICA - IBGE. Produção da Pecuária Municipal. Rio de Janeiro. Centro de Documentação e Disseminação de Informações CDDI - Coordenação de Documentação e Biblioteca CDU, 2015b.

LEMOS, B. J. M.; CASTRO, F. G. F.; SANTOS, L. S.; MENDONÇA, B. P. C.; COUTO, V. R. M.; FERNANDES, J. J. R. Monensin, virginiamycin, and flavomycin in a no-roughage finishing diet fed to zebu cattle. Journal of Animal Science, Champaign, v. 94, n. 10, p. 4307-4314, 2016. DOI: $10.2527 /$ jas2016-0504

MACEDO, F. A. F.; SIQUEIRA, E. R.; MARTINS, E. N. Desempenho de cordeiros Corriedale, puros e mestiços, terminados em pastagem e em confinamento. Arquivo Brasileiro de Medicina Veterinária e Zootecnia, Belo Horizonte, v. 51, n. 6, p. 583-587, 1999. DOI: 10.1590/ S0102-09351999000600014

MACEDO, F. A. F.; SIQUEIRA, E. R.; MARTINS, E. N. Qualidade de carcaças de Cordeiros Corriedale, Bergamácia x Corriedale e Hampshire Down x Corriedale, terminados em pastagem e confinamento. Revista Brasileira de Zootecnia, Viçosa, MG, v. 29, n. 5, p. 5201527, 2000. DOI: 10.1590/S1516-35982000000500034

MANICA, I. Fruticultura tropical 4: banana. Porto Alegre: Cinco Continentes, 1997. 485 p.

MARIE-MAGDELEINE, C.; LIMEA, L.; ETIENNE, T.; LALLO, C. H. O.; ARCHIMEDE, H.; ALEXANDRE, G. The effects of replacing Dichantium hay with banana (Musa paradisiaca) leaves and pseudo-stem on carcass traits of Ovin Martinik sheep. Tropical Animal Health and Production, Edinburgh, v. 41, n. 7, p. 1531-1538,
2009. DOI: $10.1007 / \mathrm{s} 11250-009-9344-5$

MONTANO, M. F.; MANRIQUEZ, O. M.; SALINASCHAVIRA, J.; TORRENTER A, N.; ZINN, R. A. Effects of monensin and virginiamycin supplementation in finishing diets with distiller dried grains plus solubles on growth performance and digestive function of steers. Journal of Applied Animal Research, Izatnagar, v. 43, n. 4, p. 417-425, 2015. DOI: 10.1080/09712119.2014.978785

MOREIRA, R. S. Banana: teoria e prática de cultivo. 2. ed. Campinas: Fundação Cargill, 1999. 167 p. CD-ROM.

NAVARRETE, J. D.; MONTANO, M. F.; RAYMUNDO, C.; SALINAS-CHAVIRA, J.; TORRENTERA, N.; ZINN, R. A. Efect of energy density and virginiamycin supplementation in diets on growth performance and digestive function of finishing steers. Asian-Australasian Journal of Animal Science, Seul, v. 30, n. 10, p. 13961404, 2017. DOI: 10.5713/ajas.16.0826

NUÑEZ, A. J. C.; CAETANO, M.; BERNDT, A.; DEMARCHI, J. J. A. A.; LEME, P. R.; LANNA, D. P. D. Combined use of ionophore and virginiamycin for finishing Nellore steers fed high concentrate diets. Scientia Agricola, Piracicaba, v. 70, n. 4, p. 229-236, 2013. DOI: $10.1590 / \mathrm{S} 0103-90162013000400002$

OSÓRIO, J. C.; OSÓRIO, M. T.; JARDIM, P. O.; PIMENTAL, M.; POUEY, J. L.; LÜDER, W. E.; CARDELINO, R. A.; OLIVEIRA, N. M.; GULARTE, M. A.; BORBA, M. F.; MOTTA, L.; ESTEVES, R.; MONTEIRO, E.; ZAMBIAZI, R. Métodos para avaliação da produção de carne ovina: in vivo, na carcaça e na carne. Pelotas. Editora: UFPel, 1998. 107 p.

REGULAMENTO DA INSPEÇÃO INDUSTRIAL E SANITÁRIA DE PRODUTOS DE ORIGEM ANIMAL - RIISPOA. Ministério da Agricultura, Pecuária e do Abastecimento. Brasília. Editora: Ora, 1997. 217 p.

ROGERS, J. A.; BRANINE, M. E.; MILlER, C. R.; WRAY, M. I.; BARTLE, S. J.; PRESTON, R. L.; GILL, D. R.; PRITCHARD, R. H.; STILBORN, R. P.; BECHTOL, D. T. Effects of dietary virginiamycin on performance and liver abscess incidence in feedlot cattle. Journal of Animal Science, Champaign, v. 73, n. 1, p. 9-20, 1995. DOI: $10.2527 / 1995.7319$

SALINAS-CHAVIRA, J.; BARRERAS, A.; PLASCENCIA, A.; MONTANO, M. F.; NAVARRETE, J. D.; TORRENTERA, N.; ZINN, R. A. Influence of protein nutrition and virginiamycin supplementation on feedlot growth performance and digestive function of calf-fed Holstein steers. Journal of Animal Science, Champaign, v. 94, n. 10, p. 4276-4286, 2016. DOI: 10.2527/jas2016-0576 
SALINAS-CHAVIRA, J.; LENIN, J.; PONCE, E.; SANCHEZ, U.; TORRENTERA, N.; ZINN, R. A. Comparative effects of virginiamycin supplementation on characteristics of growth-performance, dietary energetics, and digestion of calf-fed Holstein steers. Journal of Animal Science, Champaign, v. 87, n. 12, p. 4101-4108, 2009. DOI: $10.2527 /$ jas.2009-1959 